\title{
Importance Level of Construction Managers' Technical Competency Across Different Contractors' Demographics in Malaysia
}

\author{
Hairuddin Mohammad ${ }^{1, *}$, Padzil Fadzil Hassan ${ }^{1}$, and Siti Khalijah Yaman ${ }^{2}$ \\ ${ }^{1}$ Faculty of Architecture, Planning, and Survey, University Teknologi MARA, 40450 Shah Alam, \\ Selangor, Malaysia \\ ${ }^{2}$ Faculty of Civil and Environmental Engineering, University of Tun Hussein Onn Malaysia, 86400 \\ Parit Raja, Johor, Malaysia
}

\begin{abstract}
It is undeniable that construction managers play a significant role within construction phase, especially when they are representing construction contractor, one of the key stakeholders within construction project's realm. Reliance towards their technical competency is very much needed for a successfulness of a construction project. Unfortunately, a lot of recurring issues pertaining to their technical incompetency are shrouding the industry. Non-existence of term of reference for construction manager's technical competency profile is dictated as a major setback. Thus, a dedicated and comprehensive research exploration is conducted in order to bridge the gap through establishment of particular competency. Hence, in this instalment, the authors postulated a question of 'how?' which pillars on items' importance level and correlation among different contractors' demographics. Initially, data screening processes over outliers test, reliability test, and normality test were conducted. After that, the importance of technical competency for construction manager was analysed based on their central tendency (i.e. means). Finally, Spearman correlation analysis is directed towards observed ranks from diverse contractors' demographics. In a nutshell, data was free from any extreme outlier and reported high reliability value. However, data was measured as non-normal in nature. Meanwhile, through means, majority of macro items (16 items) were in a range of important (4.00) to very important (5.00). Towards the end, findings for Spearman correlation analysis were mostly leaning towards moderate and strong association's strength across different clusters of diverse contractors' demographics. Nevertheless, there were evidences that major variability of findings for both tests is exhibited through contractors' grades. Therefore, succeeding in-depth quantitative analysis is paramount in order to pin-point significant values onto each individual item.
\end{abstract}

* Corresponding author: hairuddin81@gmail.com 


\section{Introduction}

The Construction Industry Transformation Programme (CITP) which kicked in from 2016 to 2020 was a continuous effort steered by the Construction Industry Development Board (CIDB) Malaysia. Within those documents, one of its major thrust is on alleviating human capital's competency within the industry in order to enhance industry's productivity [1]. Here, issue on incompetency of construction personnel was deemed critical, which unfortunately spread throughout different level of managerial and support's clusters. In line with the conundrum, recurring problems in construction project (i.e. delays, cost overruns, subpar quality, lack of management, etc.) can be observed spawning endlessly in the background, where the contractors are usually to be blamed for such instances [2-5] (to name a few). Knowing the severe impact that will be brought into the industry, change is imminent for indigenous contractors. They must equip themselves with sufficient competency, especially in technical aspects (comprises of knowledge and skills) which become one of the key to construction successfulness, and further differentiate them with other construction practitioners [6,7].

Additionally, the pertaining issue needs not to be seen as isolated as contractor's personnel hierarchy is concerned. Given that organisation's change will incorporate full management's involvement, approach from top-to-down is paramount. Hence, the authors appreciate the fact that construction managers are the key personnel representing contractor's firm that oversee the entire construction processes. Unfortunately, there is a knowledge gap in term of established term of reference for the convenience of education, training, continuous professional development (CPD), and others, which supposed to generically spell out construction manager's technical competency. Furthermore, genuine comments from the construction managers' themselves partly became the driving force for these undertaking.

Therefore, following the previous several presented papers as in Yaman et al. [7], Mohammad et al. [6], and another one on dimensionality of items [18], this instalment proceeds with subsequent analysis on quantitative perspective as these question arose; how important are the generic technical competency of construction manager towards grade, respondents' positions, and years of experience on Malaysia's contractors (minus contractor's category, since they can have more than one category)? The need to preliminarily validate by analysing the importance of the technical competency and summing up generalised perceptions throughout entire country is paramount before subsequent detail analysis is conducted (i.e. to seek items' significant values). Therefore, the succeeding topics were brought forward which encompasses screening processes of collected data, a series of central tendencies' analysis, and simple correlation analysis, which precisely presented in a step-by-step undertakings (n.b. discussions for overall quantitative paradigm can be found in [18]).

\section{Data screening processes}

First and foremost, after data were collected and inputted into SPSS v.22, summary of respondents' demographics was tabulated as in Table 1. Furthermore, since data fits the cross-sectional survey and majority of questions employed by the Likert-Scale method, careful considerations have been made to preserve their integrity and originality. Therefore, data screening processes has been done through outliers test, reliability test, and normality test, accordingly. It was then followed by common testing for central tendency and correlation as according to classical test theory (CTT). Additionally, to assist the analysis in term of nomenclature, full abbreviations as in Table 2 will be used throughout, whereby screening processes will be considered up to Meso level of items. 
Table 1. Summary of collected data

\begin{tabular}{|c|c|c|c|}
\hline Details & & Test/Data & Results \\
\hline \multirow{24}{*}{ Actual survey } & \multicolumn{2}{|l|}{ Reliability $(\alpha)$} & 0.969 \\
\hline & \multicolumn{2}{|c|}{$100 \%$ accepted responses (minus incomplete, blank, and unsuitable responses) } & 373 no. \\
\hline & \multicolumn{2}{|c|}{ Percentage of response (self-administered) } & $47.35 \%$ \\
\hline & \multicolumn{2}{|c|}{ Percentage of response (online) } & $3.4 \%$ \\
\hline & \multirow{3}{*}{ Category of contractors } & Civil engineering & 178 no. \\
\hline & & Building construction & 219 no. \\
\hline & & Mechanical and electrical & 85 no. \\
\hline & \multirow{7}{*}{$\begin{array}{l}\text { Grade of contractors (the } \\
\text { highest number signifies } \\
\text { large size contractor) }\end{array}$} & G1 & 47 no. \\
\hline & & G2 & 25 no. \\
\hline & & G3 & 61 no. \\
\hline & & G4 & 37 no. \\
\hline & & G5 & 52 no. \\
\hline & & G6 & 28 no. \\
\hline & & G7 & 123 no. \\
\hline & \multirow{7}{*}{ Position of respondents } & Director & 131 no. \\
\hline & & Project Manager & 68 no. \\
\hline & & Contract Manager & 21 no. \\
\hline & & Construction Manager & 30 no. \\
\hline & & Site Manager & 14 no. \\
\hline & & Site Supervisor & 56 no. \\
\hline & & Architect / Engineer / Quantity Surveyor & 53 no. \\
\hline & \multirow{3}{*}{ Years of experience } & 4 years and below & 73 no. \\
\hline & & 5 years -9 years & 101 no. \\
\hline & & 10 years and above & 199 no. \\
\hline
\end{tabular}

To begin with, outliers are extreme values compared to the rest of data. It is able to show if there is any single item that has extreme recorded data which might disturb the rest of analysis. Outliers can be pre-analysed by looking at mean, 5\% trimmed mean (5\% TM, by removing $5 \%$ of extreme data), and Inter-quartile Range (IQR - above than 3 of IQR is considered Extreme Values) [8,9]. Therefore, by looking at the following table (Table 3), generally all items (variables) do not have any extreme value. Both values (i.e. mean and $5 \%$ trimmed mean) were closer to each other, and consequently attested by lower value of IQR. Hence, subsequent analysis will consider all items without any removal exercise. Apart, through reliability analysis (i.e. Cronbach Alpha, $\alpha$ ) where preferred measure of internal consistency is more than $0.7[10,11]$, a value of 0.969 is observed (see Table 1). It shows that those constructs were able to measure their intended purpose, and preliminary evidence that items were closely related as a group and supports high reliability.

Table 2. Full abbreviations used throughout the analysis

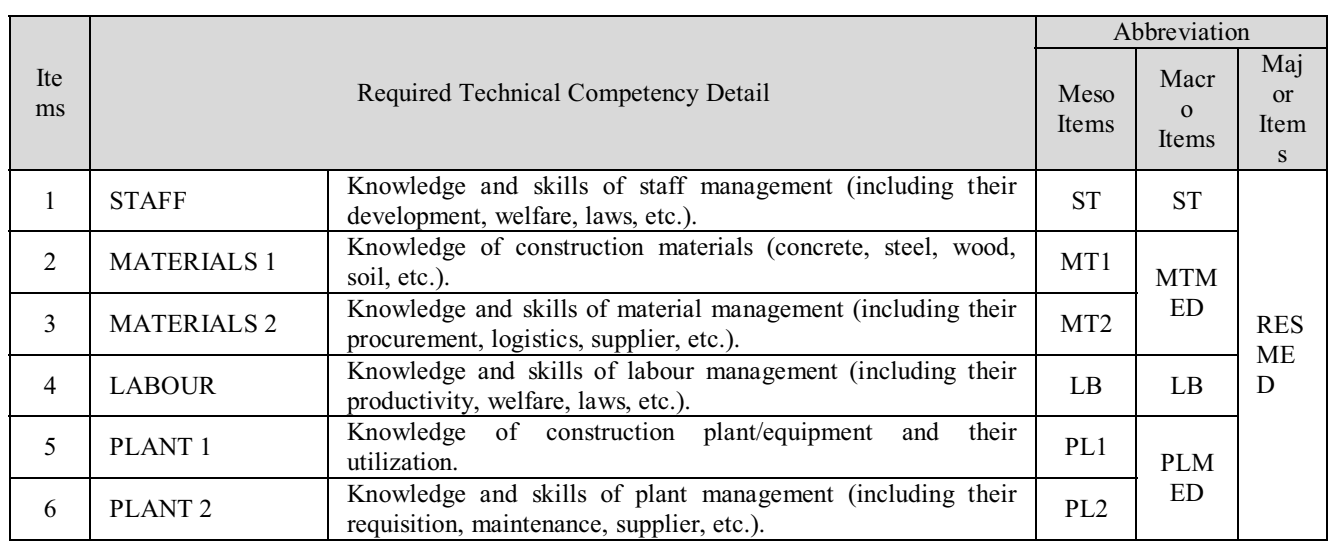




\begin{tabular}{|c|c|c|c|c|c|}
\hline 7 & $\begin{array}{l}\text { SUBCONTRACT } \\
\text { OR } 1\end{array}$ & $\begin{array}{l}\text { Knowledge and skills of sub-contractor management (including } \\
\text { their claims and payments, variations, insurances, etc.). }\end{array}$ & SU1 & \multirow{2}{*}{$\begin{array}{l}\text { SUM } \\
\text { ED }\end{array}$} & \multirow{2}{*}{$\begin{array}{l}\text { RES } \\
\text { ME } \\
\text { D }\end{array}$} \\
\hline 8 & $\begin{array}{l}\text { SUBCONTRACT } \\
\text { OR } 2\end{array}$ & $\begin{array}{l}\text { Knowledge and skills of sub-contractor tendering and bidding } \\
\text { (procedures, pretender, bid analysis, quantity take-off, etc.). }\end{array}$ & SU2 & & \\
\hline 9 & $\begin{array}{l}\text { HEALTH } \\
\text { SAFETY } 1\end{array}$ & Knowledge of health and safety equipment and manual. & HE1 & \multirow{3}{*}{$\begin{array}{c}\text { HEM } \\
\text { ED }\end{array}$} & \multirow{9}{*}{$\begin{array}{l}\text { OBJ } \\
\text { ME } \\
\text { D }\end{array}$} \\
\hline 10 & $\begin{array}{l}\text { HEALTH } \\
\text { SAFETY } 2\end{array}$ & $\begin{array}{l}\text { Knowledge and skills of health and safety management } \\
\text { (including their practices, compliance, regulation, training, } \\
\text { etc.). }\end{array}$ & HE2 & & \\
\hline 11 & $\begin{array}{l}\text { HEALTH } \\
\text { SAFETY } 3 \\
\end{array}$ & $\begin{array}{l}\text { Knowledge and skills of risk management (including their } \\
\text { assessment and analysis, etc.). }\end{array}$ & HE3 & & \\
\hline 12 & MONEY & $\begin{array}{l}\text { Knowledge and skills of financial and cost management } \\
\text { (including their claims and payments, pricing and purchasing } \\
\text { practice, etc.). }\end{array}$ & MO & MO & \\
\hline 13 & QUALITY 1 & $\begin{array}{l}\text { Knowledge of construction specifications, TQM, building codes } \\
\text { and standards, etc. }\end{array}$ & QU1 & \multirow{2}{*}{$\begin{array}{l}\text { QUM } \\
\text { ED }\end{array}$} & \\
\hline 14 & QUALITY 2 & $\begin{array}{l}\text { Knowledge and skills of quality management (including their } \\
\text { administration, assurance, quality control, etc.). }\end{array}$ & QU2 & & \\
\hline 15 & TIME & $\begin{array}{l}\text { Knowledge and skills of time management (including } \\
\text { understanding of project scheduling, updating, etc.). }\end{array}$ & TI & TI & \\
\hline 16 & $\begin{array}{l}\text { ENVIRONMENT } \\
1\end{array}$ & $\begin{array}{l}\text { Knowledge and skills of environment management (including } \\
\text { their assessment, Environment Management System (EMS), } \\
\text { etc.). }\end{array}$ & EN1 & \multirow{2}{*}{$\begin{array}{c}\text { ENM } \\
\text { ED }\end{array}$} & \\
\hline 17 & $\begin{array}{l}\text { ENVIRONMENT } \\
2\end{array}$ & $\begin{array}{l}\text { Knowledge of green and sustainable construction (including } \\
\text { Green Building Index (GBI), green construction techniques, } \\
\text { etc.). }\end{array}$ & EN2 & & \\
\hline 18 & $\begin{array}{l}\text { ADMINISTRATI } \\
\text { ON }\end{array}$ & $\begin{array}{l}\text { Knowledge and skills of construction administration (including } \\
\text { documentation and record, submissions, plans/drawings, } \\
\text { meeting, etc.). }\end{array}$ & $\mathrm{AD}$ & $\mathrm{AD}$ & \multirow{14}{*}{$\begin{array}{l}\text { GE } \\
\text { NM } \\
\text { ED }\end{array}$} \\
\hline 19 & $\begin{array}{l}\text { PRECONSTRUC } \\
\text { TION } 1\end{array}$ & $\begin{array}{l}\text { Knowledge and skills of construction site surveying, site layout, } \\
\text { temporary structures/work, etc.. }\end{array}$ & PR1 & \multirow{9}{*}{$\begin{array}{c}\text { PRM } \\
\text { ED }\end{array}$} & \\
\hline 20 & $\begin{array}{l}\text { PRECONSTRUC } \\
\text { TION } 2\end{array}$ & $\begin{array}{l}\text { Knowledge and skills of construction site management } \\
\text { (including overall resources management, master programme, } \\
\text { construction sequences, Work Breakdown Structure, project } \\
\text { start, meetings, etc.). }\end{array}$ & PR2 & & \\
\hline 21 & $\begin{array}{l}\text { PRECONSTRUC } \\
\text { TION } 3 \\
\end{array}$ & Knowledge of civil/structural design. & PR3 & & \\
\hline 22 & $\begin{array}{l}\text { PRECONSTRUC } \\
\text { TION } 4\end{array}$ & $\begin{array}{l}\text { Knowledge of construction systems (including Industrialized } \\
\text { Building System (IBS), etc.). }\end{array}$ & PR4 & & \\
\hline 23 & $\begin{array}{l}\text { PRECONSTRUC } \\
\text { TION } 5\end{array}$ & Knowledge of mechanical and electrical systems. & PR5 & & \\
\hline 24 & $\begin{array}{l}\text { PRECONSTRUC } \\
\text { TION } 6\end{array}$ & Knowledge of quantity surveying. & PR6 & & \\
\hline 25 & $\begin{array}{l}\text { PRECONSTRUC } \\
\text { TION } 7\end{array}$ & $\begin{array}{l}\text { Knowledge of Value Engineering (eliminating unnecessary cost } \\
\text { which does not contribute to the value of construction). }\end{array}$ & PR7 & & \\
\hline 26 & $\begin{array}{l}\text { PRECONSTRUC } \\
\text { TION } 8\end{array}$ & $\begin{array}{l}\text { Knowledge of Constructability (analysis of construction } \\
\text { coordination issues associated with various trades). }\end{array}$ & PR8 & & \\
\hline 27 & $\begin{array}{l}\text { PRECONSTRUC } \\
\text { TION } 9 \\
\end{array}$ & $\begin{array}{l}\text { Knowledge of Lean Construction (application of production } \\
\text { management to construction). }\end{array}$ & PR9 & & \\
\hline 28 & $\begin{array}{l}\text { CLOSEOUT \& } \\
\text { HANDOVER }\end{array}$ & $\begin{array}{l}\text { Knowledge and skills of construction closeout and handover } \\
\text { procedures (including their management, commissioning, } \\
\text { acceptance, transfer, etc.). }\end{array}$ & $\mathrm{CL}$ & $\mathrm{CL}$ & \\
\hline 29 & $\begin{array}{l}\text { RESPONSIBILITI } \\
\text { ES } 1\end{array}$ & $\begin{array}{l}\text { Knowledge and skills of construction law and legislation } \\
\text { (including authorities processing, etc.). }\end{array}$ & RS1 & \multirow{3}{*}{$\begin{array}{c}\text { RSM } \\
\text { ED }\end{array}$} & \\
\hline 30 & $\begin{array}{l}\text { RESPONSIBILITI } \\
\text { ES } 2\end{array}$ & $\begin{array}{l}\text { Knowledge and skills of construction businesses (sales, } \\
\text { commercial, trades, economic analysis, etc.). }\end{array}$ & RS2 & & \\
\hline 31 & $\begin{array}{l}\text { RESPONSIBILITI } \\
\text { ES } 3\end{array}$ & $\begin{array}{l}\text { Knowledge and skills of administering and assisting/facilitating } \\
\text { client, senior manager and junior manager (including their } \\
\text { coordination, liaison of works, orders, etc.). }\end{array}$ & RS3 & & \\
\hline 32 & $\begin{array}{l}\text { COMPUTER \& } \\
\text { I.T. } 1\end{array}$ & $\begin{array}{l}\text { Knowledge and skills of general computer application (MS } \\
\text { Excel, MS Office, Adobe, internet based, etc.). }\end{array}$ & $\mathrm{CO} 1$ & \multirow[b]{2}{*}{$\begin{array}{l}\mathrm{COM} \\
\mathrm{ED}\end{array}$} & \multirow{2}{*}{$\begin{array}{l}\text { OV } \\
\text { EM } \\
\text { ED }\end{array}$} \\
\hline 33 & $\begin{array}{l}\text { COMPUTER \& } \\
\text { I.T. } 2\end{array}$ & $\begin{array}{l}\text { Knowledge and skills of construction information technology / } \\
\text { software application (MS Project, Primavera, CAD, scheduling, } \\
\text { estimating, accounting, etc.). }\end{array}$ & $\mathrm{CO} 2$ & & \\
\hline 34 & $\begin{array}{l}\text { CONTRACT } \\
\text { ADMINISTRATI } \\
\text { ON }\end{array}$ & $\begin{array}{l}\text { Knowledge and skills of construction contracts (including their } \\
\text { administration, document, variations, Extension of Time, claims } \\
\text { and payments, subcontracts, conflict, etc.). }\end{array}$ & CT & CT & \\
\hline
\end{tabular}


Table 3. Outliers result

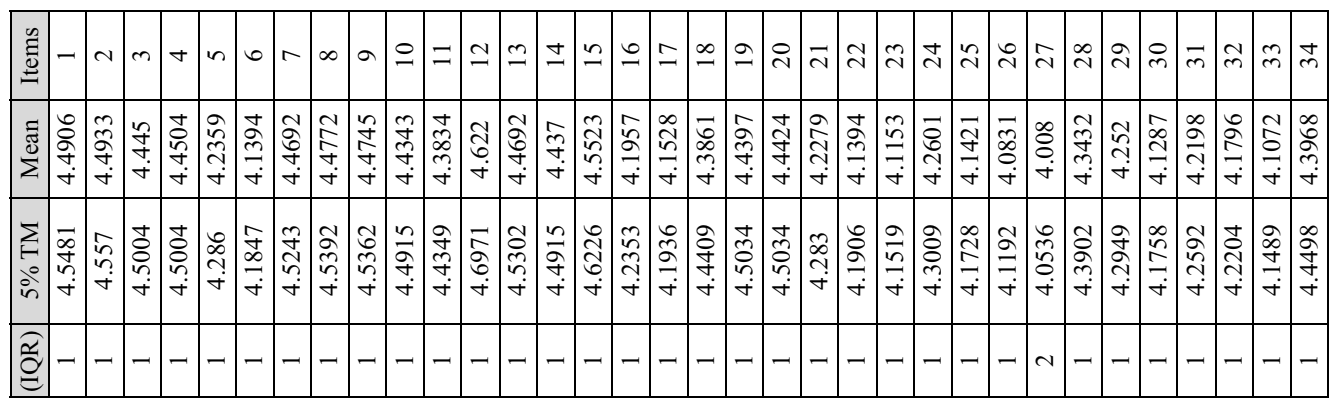

On the other hand, a normal distribution of data is a symmetric bell-shaped curve defined by two things; the mean (for average) and variance (for variability). In statistical inference, there is a central idea on sample size; when sample size increases, the distribution of data will be approximately normal. Though, in order to reduce any misleading assumption on the distribution of data, the research embarked on checking the normality of data. Additionally, since normality will determine appropriate inference's tests to be conducted afterward (either parametric test or non-parametric test), the research chose histogram analysis, skewness and kurtosis analysis, and Kolmogorov-Smirnov (K-S) and Shapiro-Wilk (S-W) test as the basis for determining normality [12]. In histogram analysis, graphical representation by using histogram that is being superimposed by the theoretical normal distribution curve provides useful information on normality of the data. Thus, each item was subjected to histogram analysis and manual observations were imposed onwards (see Fig. 1 for example). Collectively, all items were deviant to several degrees from normal and outlaid negative skewness which their tails were extending to the left side of the distributions. Therefore, in order to measure their precise deviations, subsequent analysis was conducted (i.e. skewness and kurtosis test).

In skewness analysis, the symmetry of the distribution is related to the skewness [14, 15]. Normal or perfect skewness represents a perfectly symmetric distribution. Scores that clustered to the left with their tail extending to the right are positive skewness. Scores that clustered to the right with their tail extending to the left are negative skewness. Meanwhile, the peak of the distribution is related to the kurtosis [15]. Normal or perfect kurtosis involves a distribution that is in perfect bell-shaped which is not too pointy or flat. Positive kurtosis is indicated by a peak and negative kurtosis is indicated by a flat distribution. For both analysis (i.e. skewness and kurtosis), value of " 0 " is related to perfectly normal distribution. Thus, farther away from " 0 " indicates the non-normal distribution, Mutually, as far as the particular analysis is concerned, skewness values ranges from -0.450 to -1.593 , and kurtosis values ranges from -.039 to 1.759 (with maximum standard error of 0.252 for both), when there is no observed solid " 0 " value for both aspects (see Table 4). Unfortunately, since skewness and kurtosis are being analysed separately and rely on arbitrary determination, further test by using Kolmogorov-Smirnov (K-S) and Shapiro-Wilk $(\mathrm{S}-\mathrm{W})$ was indeed needed.

Both tests (i.e. K-S and S-W) are established tests for normality that take into account for both Skewness and Kurtosis simultaneously [12]. It was designed to test normality by comparing original data to a normal distribution with the same mean and standard deviation of observed sample. K-S is preferred for large pool of respondents $(>2000)$, while the other way round for S-W $(<2000)$. Generally, hypothesis is made towards the results (by referring to significant values) as follows, $\mathrm{H}_{0}=$ there is no significant of normality, $\mathrm{H}_{1}=$ there is significant of normality, and reject $\mathrm{H}_{1}$ if p-value $<0.05$. Therefore, based on Table 5 , both tests indicate that all data are non-normal data (i.e. rejecting $\mathrm{H}_{1}$ ). For that reason, 
subsequent inference analysis will rely on non-parametric type of analysis.
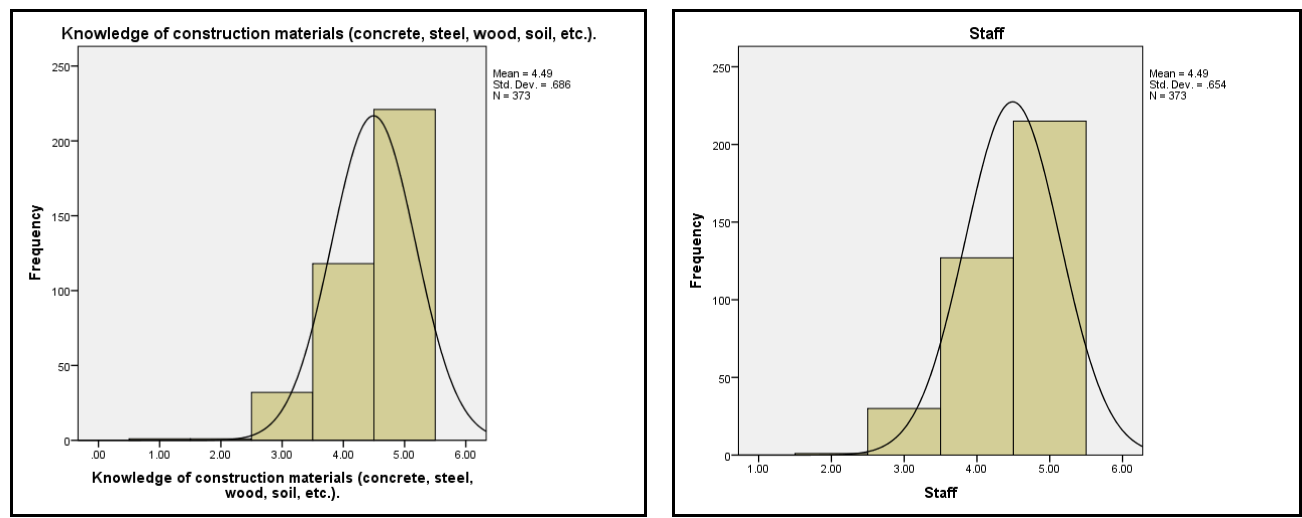

Fig. 1. Examples of histogram analysis

Table 4. Result of skewness and kurtosis analysis

\begin{tabular}{|c|c|c|c|c|c|c|c|c|c|c|c|c|c|c|c|c|c|c|c|c|c|c|c|c|c|c|}
\hline- & $-\sim$ & $m$ & + & in & 0 . & $r$ & $\infty a$ & 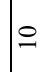 & $=$ & $\simeq \cong$ & $= \pm$ & $\because$ & $\because 7$ & $=\infty$ & $\infty=$ & iి & $\vec{\sim} \mid \tilde{N}$ & $\approx$ & $\stackrel{\sim}{\sim}$ & ?) & $\bar{\approx}$ & $\stackrel{\infty}{\infty}$ & సે & $\bar{m}$ & $\approx$ & \\
\hline & 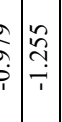 & $\begin{array}{c}\tilde{c} \\
\hat{\imath} \\
\grave{i}\end{array}$ & 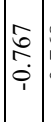 & $\begin{array}{l}\infty \\
0 \\
0 \\
0 \\
1\end{array}$ & \begin{tabular}{l}
$\simeq$ \\
\hdashline \\
$\vdots$ \\
$i$ \\
$i$
\end{tabular} & 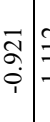 & & 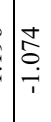 & $\mid \begin{array}{l}\infty \\
0 \\
2 \\
i \\
1\end{array}$ & 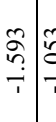 & 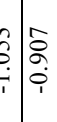 & 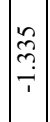 & 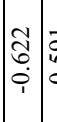 & 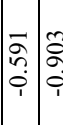 & \begin{tabular}{lll}
6 & 2 \\
0 & 0 \\
\hdashline & 0 \\
1 & -1
\end{tabular} & $\hat{2}$ & \begin{tabular}{l|l}
$\hat{n}$ & 0 \\
0 & 0 \\
& 0 \\
\end{tabular} & $\mid \begin{array}{c}\hat{N} \\
\hat{n} \\
i \\
i\end{array}$ & 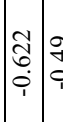 & & $\begin{array}{l}1 \\
\tilde{n} \\
\vdots \\
i\end{array}$ & & & 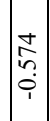 & & \\
\hline & & & $\mid \begin{array}{c}\widetilde{b} \\
0 \\
0 \\
1 \\
1\end{array}$ & & 辩 & $\begin{array}{l}\text { J } \\
0 \\
0 \\
\end{array}$ & 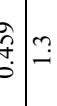 & â. & $\begin{array}{l}0 \\
2 \\
0 \\
0\end{array}$ & 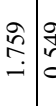 & $\begin{array}{l}0 \\
0 \\
0\end{array}$ & $\stackrel{?}{-}$ & $\mid \begin{array}{lll}n & 1 \\
& 0 \\
0 & 0 \\
0 & 0 \\
1 & 0\end{array}$ & 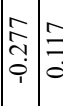 & $\begin{array}{l}E \\
\\
0\end{array}$ & $\overrightarrow{\tilde{v}}$ & $\begin{array}{ll}\frac{1}{0} \\
\\
\end{array}$ & 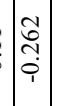 & 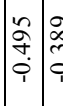 & 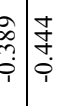 & $\begin{array}{l}\infty \\
\vdots \\
0 \\
0 \\
0\end{array}$ & 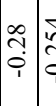 & 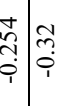 & $\frac{\alpha}{2}$ & ठิे & 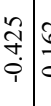 \\
\hline
\end{tabular}

Table 5. Result of Kolmogorov-Smirnov (K-S) and Shapiro-Wilk (S-W) analysis

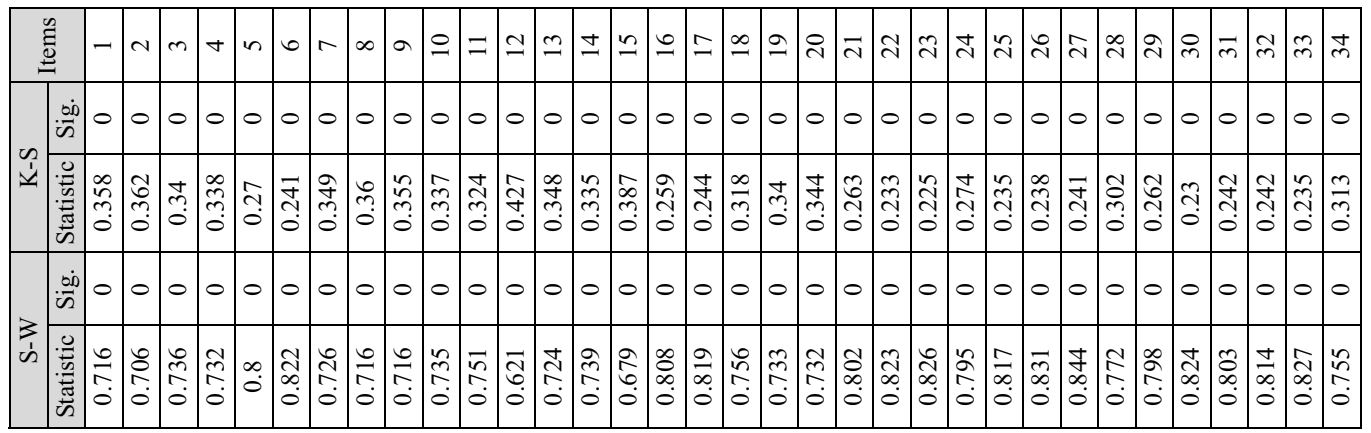

\section{Central tendency analysis}

In this section, there are two (2) minor inquiries, namely; analysing the importance level of the technical competency and correlational analysis based on contractor's demographics. Most of the works were guided by Creswell [13], and several other literatures that will be specifically cited throughout the writing. Due to the fact that contractors' demographics performed as controlled variables, summary of analysis is needed in order to discover their range of perception level. Therefore, the research only reports on the value of means, standard deviations, and further identifies their ranks according to each demographic 
cluster. Additionally, in order to give meaningful interpretation, variables were reduced to Macro level with 16 variables by using a function of 'compute variable - median' through an option of Numeric Expression in SPSS. Meanwhile, ranks were identified manually according to their respective mean value and standard deviation (SD).

From Table 6, it is worth noting that most of the contractors postulated the identified technical competency for construction manager is within the range of important (4.00) to very important (5.00). However, there were slight discrepancies on behalf of Grade 5 and Grade 6. For Grade 5 contractors, they positioned the technical competency which related to Plant and Equipment, and Computer and I.T. within the range of slightly important (3.00) to important (4.00). The same goes for Grade 6 contractors with technical competency of Computer and I.T. (see the darken boxes). Meanwhile, following Table 7 shows a summary of means based on respondent's years of experience. It can be observed that from junior to senior construction practitioners, the importance level is ranging from important (4.00) to very important (5.00). The case is quite similar for different respondents' position (see Figure 8), where anomaly is just for technical competency of Computer and I.T. on behalf of Construction Directors (with mean falls between slightly important and important).

As analysed, for 16 items across multiple control variables, there are differences of means which ranges from 3.00 (Likert scale of slightly important) to 4.00 (Likert scale of important), and from 4.00 to 5.00 (Likert scale of very important). Although the former only visualised on several instances, a focus towards contractors' grades is paramount given that most instances occurred within these control variable. However, significant trend is swiftly recognised; especially on the first cluster of technical competency for construction manager (i.e. responsibility - RESMED; such as time and money), where noticeably the respondents (across different control variables) gave extra emphasise since the recorded means of the items were significantly higher and scored greater ranks.

Table 6. Summary of importance's means and ranks of technical competency for construction manager based on contractors' grades

\begin{tabular}{|c|c|c|c|c|c|c|c|c|c|c|c|c|c|c|c|c|c|}
\hline \multicolumn{2}{|c|}{$\begin{array}{c}\text { Grade } \\
\text { registra } \\
\text { tion } \\
\text { under } \\
\text { CIDB }\end{array}$} & 穴 & $\stackrel{9}{3}$ & $\stackrel{0}{\Sigma}$ & $F$ & \& & ઇ & 七 & $\underset{\sum}{\sum_{\Sigma}^{\ominus}}$ & 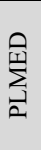 & 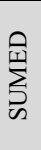 & 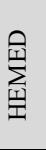 & 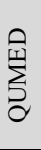 & $\sum_{\text {II }}^{\text {至 }}$ & 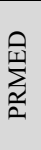 & 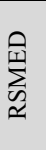 & $\sum_{0}^{\oplus}$ \\
\hline \multirow{7}{*}{$\begin{array}{c}\mathrm{G} \\
1\end{array}$} & M & 4.4 & 4.5 & 4.6 & 4.5 & 4.4 & 4.4 & 4.4 & 4.4 & 4.2 & 4.5 & 4.4 & 4.4 & 4.2 & 4.1 & 4.2 & 4.1 \\
\hline & ea & 89 & 95 & 80 & 31 & 25 & 04 & 04 & 68 & 34 & 74 & 96 & 78 & 97 & 89 & 48 & 06 \\
\hline & $\mathrm{n}$ & 4 & 7 & 9 & 9 & 5 & 3 & 3 & 1 & 0 & 5 & 5 & 7 & 9 & 1 & 2 & 4 \\
\hline & & .68 & .57 & .59 & .71 & .77 & .68 & .71 & .71 & .91 & .61 & .63 & .73 & .77 & .64 & .70 & .68 \\
\hline & D & 75 & 70 & 36 & 78 & 30 & 07 & 20 & 02 & 39 & 66 & 65 & 69 & 08 & 86 & 35 & 31 \\
\hline & & 4 & 8 & 8 & 2 & 4 & 8 & 0 & 1 & 7 & 1 & 4 & 0 & 0 & 8 & 7 & 5 \\
\hline & $\begin{array}{l}\mathrm{Ra} \\
\mathrm{nk}\end{array}$ & 6 & 2 & 1 & 4 & 9 & 10 & 11 & 8 & 14 & 3 & 5 & 7 & 12 & 15 & 13 & 16 \\
\hline \multirow{7}{*}{$\begin{array}{l}G \\
2\end{array}$} & $\mathrm{M}$ & 4.4 & 4.6 & 4.5 & 4.4 & 4.2 & 4.1 & 4.2 & 4.5 & 4.4 & 4.5 & 4.4 & 4.5 & 4.3 & 4.2 & 4.2 & 4.0 \\
\hline & ea & 40 & 40 & 20 & 40 & 80 & 20 & 40 & 60 & 40 & 00 & 66 & 20 & 40 & 80 & 26 & 60 \\
\hline & $\mathrm{n}$ & 0 & 0 & 0 & 0 & 0 & 0 & 0 & 0 & 0 & 0 & 7 & 0 & 0 & 0 & 7 & 0 \\
\hline & & .65 & .48 & .82 & .76 & .93 & .83 & .59 & .52 & .60 & .55 & .50 & .52 & .64 & .57 & .68 & .61 \\
\hline & $\begin{array}{l}\mathrm{S} \\
\mathrm{D}\end{array}$ & 06 & 99 & 26 & 81 & 63 & 26 & 72 & 67 & 06 & 90 & 00 & 99 & 09 & 74 & 53 & 77 \\
\hline & & 4 & 0 & 0 & 1 & 0 & 7 & 2 & 8 & 9 & 2 & 0 & 4 & 6 & 6 & 0 & 9 \\
\hline & $\begin{array}{l}\mathrm{Ra} \\
\mathrm{nk}\end{array}$ & 8 & 1 & 4 & 9 & 12 & 15 & 13 & 2 & 7 & 5 & 6 & 3 & 10 & 11 & 14 & 16 \\
\hline \multirow{7}{*}{$\begin{array}{c}G \\
3\end{array}$} & $\mathrm{M}$ & 4.5 & 4.5 & 4.6 & 4.6 & 4.3 & 4.3 & 4.4 & 4.5 & 4.2 & 4.5 & 4.6 & 4.3 & 4.2 & 4.2 & 4.2 & 4.2 \\
\hline & ea & 73 & 08 & 88 & 06 & 60 & 44 & 75 & 65 & 95 & 82 & 01 & 52 & 62 & 31 & 24 & 29 \\
\hline & $\mathrm{n}$ & 8 & 2 & 5 & 6 & 7 & 3 & 4 & 6 & 1 & 0 & 1 & 5 & 3 & 3 & 0 & 5 \\
\hline & & .64 & .59 & .53 & .58 & .63 & .70 & .74 & .59 & .78 & .59 & .51 & .67 & .72 & .62 & .71 & .88 \\
\hline & S & 44 & 50 & 35 & 53 & 33 & 44 & 40 & 49 & 72 & 98 & 21 & 29 & 80 & 73 & 67 & 77 \\
\hline & D & 4 & 6 & 7 & 4 & 2 & 0 & 1 & 5 & 8 & 6 & 5 & 6 & 5 & 3 & 9 & 6 \\
\hline & $\begin{array}{l}\mathrm{Ra} \\
\mathrm{nk}\end{array}$ & 5 & 7 & 1 & 2 & 9 & 11 & 8 & 6 & 12 & 4 & 3 & 10 & 13 & 14 & 16 & 15 \\
\hline
\end{tabular}




\begin{tabular}{|c|c|c|c|c|c|c|c|c|c|c|c|c|c|c|c|c|c|}
\hline \multirow{7}{*}{$\begin{array}{l}G \\
4\end{array}$} & $\mathrm{M}$ & 4.4 & 4.4 & 4.7 & 4.5 & 4.4 & 4.2 & 4.5 & 4.4 & 4.2 & 4.5 & 4.4 & 4.5 & 4.2 & 4.1 & 4.2 & 4.3 \\
\hline & ea & 05 & 32 & 02 & 67 & 32 & 43 & 67 & 86 & 43 & 00 & 14 & 13 & 16 & 83 & 97 & 64 \\
\hline & $\mathrm{n}$ & 4 & 4 & 7 & 6 & 4 & 2 & 6 & 5 & 2 & 0 & 4 & 5 & 2 & 2 & 3 & 9 \\
\hline & S & .64 & .55 & .57 & .60 & .60 & .72 & .64 & .58 & .69 & .60 & .69 & .55 & .76 & .64 & .65 & .71 \\
\hline & 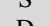 & 37 & 48 & 08 & 28 & 28 & 28 & 72 & 31 & 34 & 09 & 12 & 88 & 86 & 21 & 16 & 34 \\
\hline & & 5 & 0 & 1 & 0 & 0 & 6 & 4 & 7 & 4 & 3 & 4 & 5 & 6 & 5 & 1 & 5 \\
\hline & $\begin{array}{l}\mathrm{Ra} \\
\mathrm{nk}\end{array}$ & 10 & 7 & 1 & 2 & 8 & 14 & 3 & 6 & 13 & 5 & 9 & 4 & 15 & 16 & 12 & 11 \\
\hline \multirow{7}{*}{$\begin{array}{l}\mathrm{G} \\
5\end{array}$} & $\mathrm{M}$ & 4.3 & 4.2 & 4.5 & 4.4 & 4.4 & 4.3 & 4.2 & 4.2 & 3.8 & 4.3 & 4.3 & 4.4 & 4.0 & 4.1 & 4.1 & 3.9 \\
\hline & ea & 65 & 11 & 57 & 23 & 61 & 26 & 11 & 30 & 84 & 07 & 26 & 23 & 76 & 92 & 47 & 61 \\
\hline & $\mathrm{n}$ & 4 & 5 & 7 & 1 & 5 & 9 & 5 & 8 & 6 & 7 & 9 & 1 & 9 & 3 & 4 & 5 \\
\hline & & .74 & .80 & .66 & .69 & .69 & .70 & .80 & .75 & .86 & .70 & .76 & .67 & .72 & .60 & .71 & .74 \\
\hline & 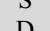 & 17 & 04 & 90 & 58 & 90 & 63 & 04 & 05 & 66 & 81 & 83 & 43 & 34 & 90 & 22 & 65 \\
\hline & & 2 & 1 & 2 & 2 & 6 & 1 & 1 & 7 & 8 & 7 & 6 & 5 & 5 & 2 & 1 & 4 \\
\hline & $\begin{array}{c}\mathrm{Ra} \\
\mathrm{nk}\end{array}$ & 5 & 10 & 1 & 4 & 2 & 6 & 11 & 9 & 16 & 8 & 7 & 3 & 14 & 12 & 13 & 15 \\
\hline \multirow{7}{*}{$\begin{array}{l}\text { G } \\
6\end{array}$} & $\mathrm{M}$ & 4.5 & 4.5 & 4.6 & 4.6 & 4.2 & 4.3 & 4.3 & 4.4 & 4.1 & 4.5 & 4.4 & 4.4 & 4.1 & 4.1 & 4.0 & 3.9 \\
\hline & ea & 35 & 00 & 78 & 07 & 14 & 57 & 57 & 82 & 78 & 00 & 16 & 28 & 96 & 94 & 59 & 64 \\
\hline & $\mathrm{n}$ & 7 & 0 & 6 & 1 & 3 & 1 & 1 & 1 & 6 & 0 & 7 & 6 & 4 & 4 & 5 & 3 \\
\hline & $\mathrm{C}$ & .69 & .74 & .66 & .62 & .83 & .67 & .62 & .68 & .58 & .69 & .68 & .66 & .82 & .62 & .67 & .75 \\
\hline & $\begin{array}{l}5 \\
\end{array}$ & 29 & 53 & 96 & 88 & 25 & 84 & 14 & 69 & 07 & 38 & 26 & 26 & 03 & 89 & 92 & 68 \\
\hline & & 3 & 6 & 4 & 9 & 4 & 7 & 8 & 4 & 8 & 9 & 8 & 9 & 4 & 9 & 2 & 0 \\
\hline & $\begin{array}{l}\mathrm{Ra} \\
\mathrm{nk}\end{array}$ & 3 & 5 & 1 & 2 & 11 & 10 & 9 & 6 & 14 & 4 & 8 & 7 & 12 & 13 & 15 & 16 \\
\hline \multirow{7}{*}{$\begin{array}{l}\mathrm{G} \\
7\end{array}$} & $\mathrm{M}$ & 4.5 & 4.4 & 4.5 & 4.5 & 4.3 & 4.3 & 4.4 & 4.4 & 4.1 & 4.4 & 4.3 & 4.4 & 4.0 & 4.2 & 4.1 & 4.1 \\
\hline & ea & 28 & 22 & 77 & 93 & 98 & 98 & 22 & 95 & 78 & 30 & 65 & 79 & 73 & 01 & 89 & 82 \\
\hline & $\mathrm{n}$ & 5 & 8 & 2 & 5 & 4 & 4 & 8 & 9 & 9 & 9 & 9 & 7 & 2 & 4 & 7 & 9 \\
\hline & & .60 & .64 & .67 & .63 & .70 & .75 & .61 & .59 & .74 & .62 & .67 & .60 & .81 & .57 & .65 & .73 \\
\hline & D & 49 & 02 & 76 & 81 & 98 & 46 & 41 & 88 & 14 & 17 & 67 & 86 & 90 & 63 & 71 & 90 \\
\hline & $D$ & 7 & 9 & 1 & 0 & 8 & 6 & 5 & 2 & 3 & 5 & 2 & 7 & 4 & 6 & 5 & 4 \\
\hline & $\begin{array}{l}\mathrm{Ra} \\
\mathrm{nk}\end{array}$ & 3 & 8 & 2 & 1 & 9 & 10 & 7 & 4 & 15 & 6 & 11 & 5 & 16 & 12 & 13 & 14 \\
\hline
\end{tabular}

Table 7. Summary of importance's means and ranks of technical competency for construction manager based on respondents' years of experience

\begin{tabular}{|c|c|c|c|c|c|c|c|c|c|c|c|c|c|c|c|c|c|}
\hline \multicolumn{2}{|c|}{$\begin{array}{l}\text { Years of } \\
\text { construct } \\
\text { ion } \\
\text { experien } \\
\text { ce }\end{array}$} & 苂 & $\stackrel{9}{3}$ & $\stackrel{0}{\Sigma}$ & $F$ & \& & $\vec{v}$ & 它 & $\underset{\sum}{\stackrel{⿴ 囗 十)}{\xi}}$ & 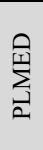 & 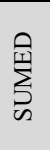 & 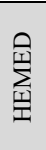 & $\sum_{0}^{0}$ & $\sum_{\text {II }}^{\text {四 }}$ & 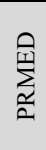 & 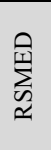 & $\sum_{0}^{0}$ \\
\hline \multirow{7}{*}{$\begin{array}{c}4 \\
\text { ye } \\
\text { ars } \\
\text { an } \\
\text { d } \\
\text { bel } \\
\text { ow }\end{array}$} & $\mathrm{M}$ & 4.4 & 4.5 & 4.5 & 4.5 & 4.4 & 4.3 & 4.3 & 4.3 & 4.1 & 4.4 & 4.4 & 4.4 & 4.2 & 4.1 & 4.2 & 4.1 \\
\hline & ea & 93 & 06 & 61 & 06 & 24 & 42 & 42 & 97 & 64 & 11 & 52 & 24 & 12 & 88 & 10 & 16 \\
\hline & $\mathrm{n}$ & 2 & 8 & 6 & 8 & 7 & 5 & 5 & 3 & 4 & 0 & 1 & 7 & 3 & 7 & 0 & 4 \\
\hline & & .70 & .68 & .72 & .74 & .76 & .74 & .67 & .71 & .84 & .76 & .78 & .68 & .82 & .64 & .74 & .77 \\
\hline & $\mathrm{S}$ & 95 & 96 & 62 & 76 & 22 & 94 & 12 & 66 & 18 & 98 & 83 & 04 & 03 & 96 & 84 & 96 \\
\hline & D & 2 & 7 & 2 & 5 & 7 & 3 & 2 & 6 & 5 & 4 & 6 & 4 & 9 & 5 & 7 & 0 \\
\hline & $\begin{array}{l}\mathrm{Ra} \\
\mathrm{nk}\end{array}$ & 4 & 2 & 1 & 3 & 7 & 12 & 11 & 10 & 8 & 9 & 5 & 6 & 13 & 15 & 14 & 16 \\
\hline \multirow{7}{*}{$\begin{array}{c}5 \\
\text { ye } \\
\text { ars } \\
-9 \\
\text { ye } \\
\text { ars }\end{array}$} & $\mathrm{M}$ & 4.4 & 4.3 & 4.5 & 4.4 & 4.3 & 4.1 & 4.3 & 4.3 & 4.0 & 4.3 & 4.3 & 4.4 & 4.1 & 4.0 & 4.1 & 4.1 \\
\hline & ea & 05 & 06 & 34 & 45 & 46 & 58 & 66 & 56 & 64 & 96 & 69 & 30 & 23 & 96 & 22 & 18 \\
\hline & $\mathrm{n}$ & 9 & 9 & 7 & 5 & 5 & 4 & 3 & 4 & 4 & 0 & 6 & 7 & 8 & 8 & 1 & 8 \\
\hline & & .69 & .67 & .64 & .67 & .75 & .74 & .67 & .65 & .77 & .61 & .65 & .65 & .80 & .65 & .70 & .72 \\
\hline & $\begin{array}{l}\mathrm{S} \\
\mathrm{D}\end{array}$ & 53 & 44 & 13 & 04 & 41 & 47 & 41 & 70 & 02 & 36 & 47 & 58 & 12 & 42 & 98 & 85 \\
\hline & D & 9 & 3 & 2 & 5 & 3 & 5 & 3 & 3 & 7 & 6 & 3 & 6 & 7 & 7 & 1 & 2 \\
\hline & $\begin{array}{l}\mathrm{Ra} \\
\mathrm{nk}\end{array}$ & 4 & 10 & 1 & 2 & 9 & 11 & 7 & 8 & 16 & 5 & 6 & 3 & 12 & 15 & 13 & 14 \\
\hline \multirow{7}{*}{$\begin{array}{c}10 \\
\text { ye } \\
\text { ars } \\
\text { an } \\
\text { d } \\
\text { ab } \\
\text { ov } \\
\text { e }\end{array}$} & $\mathrm{M}$ & 4.5 & 4.5 & 4.6 & 4.6 & 4.3 & 4.4 & 4.4 & 4.5 & 4.2 & 4.5 & 4.4 & 4.4 & 4.1 & 4.2 & 4.2 & 4.1 \\
\hline & ea & 32 & 02 & 88 & 23 & 92 & 37 & 32 & 52 & 58 & 35 & 53 & 74 & 85 & 68 & 36 & 65 \\
\hline & $\mathrm{n}$ & 7 & 5 & 4 & 1 & 0 & 2 & 2 & 8 & 8 & 2 & 9 & 9 & 9 & 6 & 2 & 8 \\
\hline & & .60 & .61 & .60 & .59 & .68 & .69 & .69 & .59 & .74 & .57 & .59 & .61 & .73 & .55 & .63 & .76 \\
\hline & $\begin{array}{l}\mathrm{S} \\
\mathrm{D}\end{array}$ & 94 & 03 & 58 & 77 & 69 & 25 & 20 & 11 & 67 & 84 & 92 & 49 & 72 & 49 & 87 & 22 \\
\hline & D & 3 & 0 & 8 & 0 & 2 & 5 & 7 & 6 & 8 & 6 & 7 & 4 & 5 & 0 & 7 & 0 \\
\hline & $\begin{array}{l}\mathrm{Ra} \\
\mathrm{nk}\end{array}$ & 5 & 6 & 1 & 2 & 11 & 9 & 10 & 3 & 13 & 4 & 8 & 7 & 15 & 12 & 14 & 16 \\
\hline
\end{tabular}


Table 8. Summary of importance's means and ranks of technical competency for construction manager based on respondents' positions

\begin{tabular}{|c|c|c|c|c|c|c|c|c|c|c|c|c|c|c|c|c|c|}
\hline \multicolumn{2}{|c|}{ Positions } & 它 & $\stackrel{9}{コ}$ & $\stackrel{0}{\Sigma}$ & $F$ & 完 & $\vec{U}$ & 它 & $\sum_{j}^{\mu}$ & 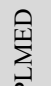 & 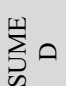 & 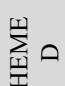 & $\sum_{2}^{\infty}$ & $\sum_{i=1}^{\infty} 0$ & 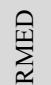 & 至 & $\sum_{0}^{1} \theta$ \\
\hline \multirow{5}{*}{$\begin{array}{l}\text { Direc } \\
\text { tor }\end{array}$} & $\begin{array}{c}\text { Mea } \\
\mathrm{n}\end{array}$ & $\begin{array}{r}4.4 \\
42 \\
\end{array}$ & $\begin{array}{r}4.3 \\
89 \\
\end{array}$ & $\begin{array}{r}4.7 \\
02\end{array}$ & $\begin{array}{r}4.5 \\
42\end{array}$ & $\begin{array}{r}4.3 \\
74\end{array}$ & $\begin{array}{r}4.3 \\
28\end{array}$ & $\begin{array}{r}4.3 \\
74\end{array}$ & $\begin{array}{r}4.4 \\
31\end{array}$ & $\begin{array}{r}4.0 \\
72\end{array}$ & $\begin{array}{r}4.4 \\
73\end{array}$ & $\begin{array}{r}4.3 \\
41\end{array}$ & $\begin{array}{r}4.4 \\
16\end{array}$ & $\begin{array}{r}4.1 \\
56\end{array}$ & $\begin{array}{r}4.1 \\
27\end{array}$ & $\begin{array}{r}4.1 \\
57\end{array}$ & $\begin{array}{r}3.9 \\
88\end{array}$ \\
\hline & $\begin{array}{l}\text { Std. } \\
\text { Dev }\end{array}$ & .70 & .70 & .61 & .65 & .68 & .68 & .69 & .70 & .83 & .66 & .71 & .68 & .77 & .63 & .71 & .75 \\
\hline & iatio & 34 & 79 & 63 & 93 & 31 & 43 & 43 & 91 & 00 & 30 & 06 & 26 & 23 & 90 & 53 & 82 \\
\hline & $\mathrm{n}$ & & & & 6 & 6 & 6 & 3 & 8 & 2 & 7 & 8 & 2 & 2 & 5 & 1 & 0 \\
\hline & $\begin{array}{c}\text { Ran } \\
k\end{array}$ & 4 & 7 & 1 & 2 & 8 & 11 & 9 & 5 & 15 & 3 & 10 & 6 & 13 & 14 & 12 & 16 \\
\hline \multirow{5}{*}{$\begin{array}{c}\text { Proje } \\
\text { ct } \\
\text { Mana } \\
\text { ger }\end{array}$} & $\begin{array}{c}\text { Mea } \\
\mathrm{n}\end{array}$ & $\begin{array}{r}4.5 \\
29\end{array}$ & $\begin{array}{r}4.5 \\
73\end{array}$ & $\begin{array}{r}4.6 \\
32\end{array}$ & $\begin{array}{r}4.6 \\
61\end{array}$ & $\begin{array}{r}4.4 \\
85\end{array}$ & $\begin{array}{r}4.5 \\
14\end{array}$ & $\begin{array}{r}4.5 \\
88\end{array}$ & $\begin{array}{r}4.5 \\
80\end{array}$ & $\begin{array}{r}4.3 \\
38\end{array}$ & $\begin{array}{r}4.5 \\
73\end{array}$ & $\begin{array}{r}4.5 \\
19\end{array}$ & $\begin{array}{r}4.5 \\
80\end{array}$ & $\begin{array}{r}4.2 \\
79\end{array}$ & $\begin{array}{r}4.3 \\
21\end{array}$ & $\begin{array}{r}4.3 \\
72\end{array}$ & $\begin{array}{r}4.2 \\
79\end{array}$ \\
\hline & Std. & .63 & .58 & .59 & .53 & .72 & .63 & .57 & .51 & .73 & .52 & .59 & .50 & .75 & .56 & .57 & .67 \\
\hline & $\begin{array}{l}\text { Dev } \\
\text { iatio }\end{array}$ & 41 & 12 & 61 & 56 & 26 & 46 & 91 & 55 & 52 & 02 & 12 & 82 & 00 & 85 & 74 & 12 \\
\hline & $\mathrm{n}$ & 2 & 0 & 2 & 1 & 1 & 4 & 2 & 1 & 6 & 2 & 1 & 2 & 4 & 5 & 3 & 8 \\
\hline & $\begin{array}{c}\text { Ran } \\
k\end{array}$ & 8 & 7 & 2 & 1 & 11 & 10 & 3 & 4 & 13 & 6 & 9 & 5 & 16 & 14 & 12 & 15 \\
\hline \multirow{5}{*}{$\begin{array}{l}\text { Contr } \\
\text { act } \\
\text { Mana } \\
\text { ger }\end{array}$} & $\begin{array}{c}\text { Mea } \\
\mathrm{n}\end{array}$ & $\begin{array}{r}4.4 \\
76\end{array}$ & $\begin{array}{r}4.3 \\
33\end{array}$ & $\begin{array}{r}4.7 \\
61\end{array}$ & $\begin{array}{r}4.6 \\
19\end{array}$ & $\begin{array}{r}4.5 \\
71\end{array}$ & $\begin{array}{r}4.5 \\
71\end{array}$ & $\begin{array}{r}4.4 \\
28\end{array}$ & $\begin{array}{r}4.5 \\
23\end{array}$ & $\begin{array}{r}4.2 \\
38\end{array}$ & $\begin{array}{r}4.5 \\
23\end{array}$ & $\begin{array}{r}4.4 \\
28\end{array}$ & $\begin{array}{r}4.5 \\
71\end{array}$ & $\begin{array}{r}4.0 \\
71\end{array}$ & $\begin{array}{r}4.3 \\
59\end{array}$ & $\begin{array}{r}4.2 \\
38\end{array}$ & $\begin{array}{r}4.0 \\
47\end{array}$ \\
\hline & Std. & .60 & .65 & .43 & .58 & .74 & .74 & .81 & .51 & .80 & .60 & .65 & .74 & .67 & .54 & .63 & .80 \\
\hline & Dev & 15 & 82 & 64 & 95 & 64 & 64 & 06 & 17 & 03 & 15 & 94 & 64 & 61 & 08 & 37 & 47 \\
\hline & n & 9 & 8 & 4 & 9 & 2 & 2 & 4 & 7 & 0 & 9 & 9 & 2 & 2 & 1 & 1 & 5 \\
\hline & $\begin{array}{c}\text { Ran } \\
k\end{array}$ & 6 & 10 & 1 & 2 & 3 & 3 & 8 & 4 & 12 & 5 & 7 & 3 & 13 & 9 & 11 & 14 \\
\hline \multirow{5}{*}{$\begin{array}{c}\text { Const } \\
\text { ructio } \\
n \\
\text { Mana } \\
\text { ger }\end{array}$} & $\begin{array}{c}\text { Mea } \\
\mathrm{n}\end{array}$ & $\begin{array}{r}4.4 \\
33 \\
\end{array}$ & $\begin{array}{r}4.5 \\
66 \\
\end{array}$ & $\begin{array}{r}4.5 \\
66 \\
\end{array}$ & $\begin{array}{r}4.4 \\
66 \\
\end{array}$ & $\begin{array}{r}4.2 \\
33 \\
\end{array}$ & $\begin{array}{r}4.1 \\
00\end{array}$ & $\begin{array}{r}4.3 \\
00\end{array}$ & $\begin{array}{r}4.4 \\
50\end{array}$ & $\begin{array}{r}4.2 \\
66 \\
\end{array}$ & $\begin{array}{r}4.3 \\
16 \\
\end{array}$ & $\begin{array}{r}4.3 \\
00\end{array}$ & $\begin{array}{r}4.2 \\
66 \\
\end{array}$ & $\begin{array}{r}4.0 \\
33\end{array}$ & $\begin{array}{r}4.0 \\
03\end{array}$ & $\begin{array}{r}4.0 \\
66 \\
\end{array}$ & $\begin{array}{r}4.1 \\
50\end{array}$ \\
\hline & $\begin{array}{l}\text { Std. } \\
\text { Dev }\end{array}$ & .62 & .50 & .62 & .68 & .72 & .71 & .59 & .67 & .79 & .63 & .76 & .61 & .96 & .61 & .72 & .60 \\
\hline & Dev & 60 & 40 & 60 & 14 & 79 & 19 & 59 & 40 & 58 & 63 & 98 & 21 & 43 & 72 & 39 & 38 \\
\hline & $\begin{array}{c}\text { Iato } \\
\mathrm{n}\end{array}$ & 6 & 1 & 6 & 5 & 3 & 7 & 6 & 3 & 2 & 1 & 8 & 4 & 1 & 5 & 7 & 7 \\
\hline & $\begin{array}{c}\text { Ran } \\
k\end{array}$ & 5 & 1 & 2 & 3 & 11 & 13 & 7 & 4 & 10 & 6 & 8 & 9 & 15 & 16 & 14 & 12 \\
\hline \multirow{5}{*}{$\begin{array}{l}\text { Site } \\
\text { Mana } \\
\text { ger }\end{array}$} & $\begin{array}{c}\text { Mea } \\
\mathrm{n}\end{array}$ & $\begin{array}{r}4.5 \\
00 \\
\end{array}$ & $\begin{array}{r}4.5 \\
71 \\
\end{array}$ & $\begin{array}{r}4.4 \\
28\end{array}$ & $\begin{array}{r}4.3 \\
57 \\
\end{array}$ & $\begin{array}{r}4.2 \\
85 \\
\end{array}$ & $\begin{array}{r}4.2 \\
14 \\
\end{array}$ & $\begin{array}{r}4.0 \\
00 \\
\end{array}$ & $\begin{array}{r}4.6 \\
42\end{array}$ & $\begin{array}{r}3.8 \\
92\end{array}$ & $\begin{array}{r}4.3 \\
92\end{array}$ & $\begin{array}{r}4.3 \\
57\end{array}$ & $\begin{array}{r}4.4 \\
28\end{array}$ & $\begin{array}{r}4.1 \\
07\end{array}$ & $\begin{array}{r}4.1 \\
34\end{array}$ & $\begin{array}{r}4.0 \\
47\end{array}$ & $\begin{array}{r}4.0 \\
7\end{array}$ \\
\hline & $\begin{array}{l}\text { Std. } \\
\text { Dev }\end{array}$ & .65 & .51 & .93 & .74 & .61 & .80 & .67 & .60 & .65 & .83 & .82 & .51 & .92 & .50 & .78 & .82 \\
\hline & Dev & 04 & 35 & 76 & 49 & 12 & 17 & 93 & 21 & 57 & 61 & 13 & 35 & 35 & 10 & 29 & 87 \\
\hline & $\mathrm{n}$ & 4 & 5 & 1 & 5 & 5 & 8 & 7 & 9 & 0 & 7 & 4 & 5 & 9 & 5 & 1 & 4 \\
\hline & $\begin{array}{c}\text { Ran } \\
\mathrm{k}\end{array}$ & 3 & 2 & 5 & 7 & 9 & 10 & 15 & 1 & 16 & 6 & 8 & 4 & 12 & 11 & 14 & 13 \\
\hline \multirow{5}{*}{$\begin{array}{l}\text { Site } \\
\text { Super } \\
\text { visor }\end{array}$} & $\begin{array}{c}\text { Mea } \\
\mathrm{n}\end{array}$ & $\begin{array}{r}4.4 \\
10 \\
\end{array}$ & $\begin{array}{r}4.3 \\
75 \\
\end{array}$ & $\begin{array}{r}4.3 \\
57 \\
\end{array}$ & $\begin{array}{r}4.4 \\
64 \\
\end{array}$ & $\begin{array}{r}4.2 \\
85 \\
\end{array}$ & $\begin{array}{r}4.2 \\
32 \\
\end{array}$ & $\begin{array}{r}4.3 \\
03 \\
\end{array}$ & $\begin{array}{r}4.2 \\
58\end{array}$ & $\begin{array}{r}4.1 \\
42\end{array}$ & $\begin{array}{r}4.3 \\
75\end{array}$ & $\begin{array}{r}4.4 \\
88\end{array}$ & $\begin{array}{r}4.4 \\
01\end{array}$ & $\begin{array}{r}4.2 \\
23\end{array}$ & $\begin{array}{r}4.2 \\
48\end{array}$ & $\begin{array}{r}4.1 \\
42\end{array}$ & $\begin{array}{r}4.2 \\
05\end{array}$ \\
\hline & Std. & .70 & .67 & .79 & .78 & .82 & .87 & .78 & .69 & .78 & .68 & .55 & .69 & .70 & .61 & .73 & .80 \\
\hline & & 78 & 58 & 60 & 54 & 49 & 36 & 43 & 40 & 45 & 25 & 76 & 03 & 01 & 29 & 26 & 21 \\
\hline & $\begin{array}{c}\text { 1at1o } \\
\mathrm{n}\end{array}$ & 0 & 8 & 9 & 2 & 4 & 8 & 8 & 7 & 9 & 8 & 4 & 2 & 3 & 9 & 6 & 4 \\
\hline & $\begin{array}{c}\text { Ran } \\
\mathrm{k}\end{array}$ & 3 & 5 & 7 & 2 & 9 & 12 & 8 & 10 & 16 & 6 & 1 & 4 & 13 & 11 & 15 & 14 \\
\hline \multirow{5}{*}{$\begin{array}{l}\text { Arch. } \\
\text { / } \\
\text { Eng. } \\
\text { / QS }\end{array}$} & $\begin{array}{c}\text { Mea } \\
n\end{array}$ & $\begin{array}{r}4.6 \\
79\end{array}$ & $\begin{array}{r}4.4 \\
71\end{array}$ & $\begin{array}{r}4.7 \\
17\end{array}$ & $\begin{array}{r}4.6 \\
03\end{array}$ & $\begin{array}{r}4.4 \\
34\end{array}$ & $\begin{array}{r}4.3 \\
58\end{array}$ & $\begin{array}{r}4.4 \\
52\end{array}$ & $\begin{array}{r}4.5 \\
84\end{array}$ & $\begin{array}{r}4.3 \\
39\end{array}$ & $\begin{array}{r}4.5 \\
37\end{array}$ & $\begin{array}{r}4.5 \\
72\end{array}$ & $\begin{array}{r}4.5 \\
00\end{array}$ & $\begin{array}{r}4.1 \\
69\end{array}$ & $\begin{array}{r}4.2 \\
83\end{array}$ & $\begin{array}{r}4.2 \\
45\end{array}$ & $\begin{array}{r}4.3 \\
39\end{array}$ \\
\hline & $\begin{array}{l}\text { Std. } \\
\text { Dev }\end{array}$ & .51 & .63 & .49 & .59 & .69 & .70 & .60 & .53 & .63 & .57 & .53 & .60 & .75 & .56 & .61 & .78 \\
\hline & iatio & 04 & 86 & 52 & 93 & 36 & 96 & 65 & 47 & 37 & 05 & 66 & 44 & 28 & 59 & 02 & 91 \\
\hline & $\mathrm{n}$ & 1 & 2 & 6 & 5 & 4 & 7 & 7 & 2 & 7 & 0 & 0 & 7 & 4 & 6 & 8 & 9 \\
\hline & $\begin{array}{c}\text { Ran } \\
\mathrm{k}\end{array}$ & 2 & 8 & 1 & 3 & 10 & 11 & 9 & 4 & 12 & 6 & 5 & 7 & 16 & 14 & 15 & 13 \\
\hline
\end{tabular}




\section{Nonparametric correlation analysis}

Due to the fact that all data are considered non-normal, thus, correlation analysis will be conducted through Spearman's Rho analysis. Prior assumption of single-dimensionality of items (i.e. all items contribute to construction manager's technical competency) facilitated the analysis, where their strength of associations was put to test amid diverse clusters in each respective control variables. In line, given that Spearman's Rho mutually relies on ranks of data, findings from the previous analysis were beneficial. Aside from determining the direction of correlations (i.e. positive or negative) among items across different control variables, their observable strength is very much significant in order to describe their degree of associations and further shed some light on subsequent focus towards appropriate control variables. Therefore, based on $[16,17]$, correlational strength index is defined as weak (at $r \leq 0.5$ ), moderate (at $0.5<\mathrm{r}<0.8$ ), and strong (at $\mathrm{r} \geq 0.8$ ).

Initially, the following table (see Table 9) presented a finding from correlation analysis for diverse contractors' grades. In summary, moderate to strong correlational strength is profound. Nevertheless, there is significantly weak correlation strength that can be detected especially towards G2 contractors towards G4, G5, and G7. On the other hand, as respondents' diverse experience (see Table 10) and positions (see Table 11) is concerned, correlational strength index of moderate to strong dominates the tabulations, except for one; between contract managers and construction managers. All correlations denote positive values which eventually manifested positive linear correlations, where increment values for both cluster of control variables were judged to be perpendicular to each other.

Table 9. Summary of correlation analysis across different contractors' grades

\begin{tabular}{|c|c|c|c|c|c|c|c|c|c|}
\hline & & & G1 & G2 & G3 & G4 & G5 & G6 & G7 \\
\hline \multirow[t]{21}{*}{ Spearman's rho } & \multirow[t]{3}{*}{ G1 } & $\begin{array}{l}\text { Correlation } \\
\text { Coefficient }\end{array}$ & 1.000 & $.700^{* *}$ & $.891^{* *}$ & $.712^{* *}$ & $.715^{* *}$ & $.924^{* *}$ & $.756^{* *}$ \\
\hline & & Sig. (2-tailed) & & .003 & .000 & .002 & .002 & .000 & .001 \\
\hline & & $\mathrm{N}$ & 16 & 16 & 16 & 16 & 16 & 16 & 16 \\
\hline & \multirow[t]{3}{*}{ G2 } & $\begin{array}{l}\text { Correlation } \\
\text { Coefficient }\end{array}$ & $.700^{* *}$ & 1.000 & $.594^{*}$ & .476 & .312 & $.653^{* *}$ & .482 \\
\hline & & Sig. (2-tailed) & .003 & & .015 & .062 & .240 & .006 & .058 \\
\hline & & $\mathrm{N}$ & 16 & 16 & 16 & 16 & 16 & 16 & 16 \\
\hline & \multirow[t]{3}{*}{ G3 } & $\begin{array}{l}\text { Correlation } \\
\text { Coefficient }\end{array}$ & $.891^{* *}$ & $.594^{*}$ & 1.000 & $.744^{* *}$ & $.682^{* *}$ & $.918^{* *}$ & \\
\hline & & Sig. (2-tailed) & .000 & .015 & & .001 & .004 & .000 & .000 \\
\hline & & $\mathrm{N}$ & 16 & 16 & 16 & 16 & 16 & 16 & 16 \\
\hline & \multirow[t]{3}{*}{ G4 } & $\begin{array}{l}\text { Correlation } \\
\text { Coefficient }\end{array}$ & $.712^{* *}$ & .476 & $.744^{* *}$ & 1.000 & $.606^{*}$ & $.738^{* *}$ & $.815^{* *}$ \\
\hline & & Sig. (2-tailed) & .002 & .062 & .001 & & .013 & .001 & .000 \\
\hline & & $\mathrm{N}$ & 16 & 16 & 16 & 16 & 16 & 16 & 16 \\
\hline & \multirow[t]{3}{*}{ G5 } & $\begin{array}{l}\text { Correlation } \\
\text { Coefficient }\end{array}$ & $.715^{* *}$ & .312 & $.682^{* *}$ & $.606^{*}$ & 1.000 & $.721^{* *}$ & $.774^{* *}$ \\
\hline & & Sig. (2-tailed) & .002 & .240 & .004 & .013 & & .002 & .000 \\
\hline & & $\mathrm{N}$ & 16 & 16 & 16 & 16 & 16 & 16 & 16 \\
\hline & \multirow[t]{3}{*}{ G6 } & $\begin{array}{l}\text { Correlation } \\
\text { Coefficient }\end{array}$ & $.924^{* *}$ & $.653^{* *}$ & $.918^{* *}$ & $.738^{* *}$ & $.721^{* *}$ & 1.000 & $.903^{* *}$ \\
\hline & & Sig. (2-tailed) & .000 & .006 & .000 & .001 & .002 & & .000 \\
\hline & & $\mathrm{N}$ & 16 & 16 & 16 & 16 & 16 & 16 & 16 \\
\hline & \multirow[t]{3}{*}{ G7 } & $\begin{array}{l}\text { Correlation } \\
\text { Coefficient }\end{array}$ & $.756^{* *}$ & .482 & $.797^{* *}$ & $.815^{* *}$ & $.774^{* *}$ & $.903^{* *}$ & 1.000 \\
\hline & & Sig. (2-tailed) & .001 & .058 & .000 & .000 & .000 & .000 & \\
\hline & & $\mathrm{N}$ & 16 & 16 & 16 & 16 & 16 & 16 & 16 \\
\hline
\end{tabular}


Table 10. Summary of correlation analysis across different respondents' years of experience

\begin{tabular}{|c|c|c|c|c|c|}
\hline & & & $\begin{array}{l}4 \text { years and } \\
\text { below }\end{array}$ & 5 years & $\begin{array}{l}10 \text { years and } \\
\text { above }\end{array}$ \\
\hline \multirow[t]{9}{*}{ Spearman's rho } & \multirow{3}{*}{$\begin{array}{l}4 \text { year } \\
\text { below }\end{array}$} & andCorrelation Coefficient & 1.000 & $.726^{6}$ & $.756^{*}$ \\
\hline & & Sig. (2-tailed) & & .001 & .001 \\
\hline & & $\mathrm{N}$ & 16 & 16 & 16 \\
\hline & \multirow{2}{*}{\multicolumn{2}{|c|}{5 years - 9 years Correlation Coefficient }} & $.726^{* *}$ & 1.000 & $.835^{* *}$ \\
\hline & & & .001 & & .000 \\
\hline & \multicolumn{2}{|r|}{$\mathrm{N}$} & 16 & 16 & 16 \\
\hline & \multirow{3}{*}{$\begin{array}{l}10 \text { yea } \\
\text { above }\end{array}$} & andCorrelation Coefficient & $.756^{* *}$ & $.835^{* *}$ & 1.000 \\
\hline & & Sig. (2-tailed) & .001 & .000 & \\
\hline & & $\mathrm{N}$ & 16 & 16 & 16 \\
\hline
\end{tabular}

Table 11. Summary of correlation analysis across different respondents' positions

\begin{tabular}{|c|c|c|c|c|c|c|c|c|}
\hline & & Director & \begin{tabular}{|l|} 
Project \\
Manager
\end{tabular} & \begin{tabular}{|l|} 
Contract \\
Manager
\end{tabular} & $\begin{array}{l}\text { Construction } \\
\text { Manager }\end{array}$ & \begin{tabular}{|l|} 
Site \\
Manager
\end{tabular} & \begin{tabular}{|l|} 
Site \\
Supervisor
\end{tabular} & $\begin{array}{l}\text { Architect } \\
\text { and etc. }\end{array}$ \\
\hline \multirow[t]{3}{*}{$\begin{array}{l}\text { Spearman'sDirector } \\
\text { rho }\end{array}$} & $\begin{array}{l}\text { Correlation } \\
\text { Coefficient }\end{array}$ & 1.000 & $.868^{* *}$ & $.788^{* *}$ & $.806^{* *}$ & $.762^{* *}$ & $.726^{* *}$ & $.879^{* *}$ \\
\hline & $\begin{array}{l}\text { Sig. (2- } \\
\text { tailed) }\end{array}$ & & .000 & .000 & .000 & .001 & .001 & .000 \\
\hline & $\mathrm{N}$ & 16 & 16 & 16 & 16 & 16 & 16 & 16 \\
\hline \multirow[t]{3}{*}{$\begin{array}{l}\text { Project } \\
\text { Manager }\end{array}$} & $\begin{array}{l}\text { Correlation } \\
\text { Coefficient }\end{array}$ & $868^{* *}$ & 1.000 & $.735^{* *}$ & $.826^{* *}$ & $.565^{*}$ & $.668^{* *}$ & $.832^{* *}$ \\
\hline & $\begin{array}{l}\text { Sig. (2- } \\
\text { tailed) }\end{array}$ & .000 & . & .001 & .000 & .023 & .005 & .000 \\
\hline & $\mathrm{N}$ & 16 & 16 & 16 & 16 & 16 & 16 & 16 \\
\hline \multirow[t]{3}{*}{$\begin{array}{l}\text { Contract } \\
\text { Manager }\end{array}$} & $\begin{array}{l}\text { Correlation } \\
\text { Coefficient }\end{array}$ & $.788^{* *}$ & $.735^{* *}$ & 1.000 & .469 & $.555^{*}$ & $.558^{*}$ & $.711^{* *}$ \\
\hline & $\begin{array}{l}\text { Sig. (2- } \\
\text { tailed) }\end{array}$ & .000 & .001 & & .067 & .026 & .025 & .002 \\
\hline & $\mathrm{N}$ & 16 & 16 & 16 & 16 & 16 & 16 & 16 \\
\hline \multirow[t]{3}{*}{$\begin{array}{l}\text { Construction } \\
\text { Manager }\end{array}$} & $\begin{array}{l}\text { Correlation } \\
\text { Coefficient }\end{array}$ & $806^{* *}$ & $.826^{* *}$ & .469 & 1.000 & $.688^{* *}$ & $.659^{* *}$ & $.865^{* *}$ \\
\hline & $\begin{array}{l}\text { Sig. (2- } \\
\text { tailed) }\end{array}$ & .000 & .000 & .067 & & .003 & .006 & .000 \\
\hline & $\mathrm{N}$ & 16 & 16 & 16 & 16 & 16 & 16 & 16 \\
\hline \multirow[t]{3}{*}{$\begin{array}{l}\text { Site } \\
\text { Manager }\end{array}$} & $\begin{array}{l}\text { Correlation } \\
\text { Coefficient }\end{array}$ & $762^{* *}$ & $.565^{*}$ & $.555^{*}$ & $.688^{* *}$ & 1.000 & $.671^{* *}$ & $.741^{* *}$ \\
\hline & $\begin{array}{l}\text { Sig. (2- } \\
\text { tailed) }\end{array}$ & .001 & .023 & .026 & .003 & & .004 & .001 \\
\hline & $\mathrm{N}$ & 16 & 16 & 16 & 16 & 16 & 16 & 16 \\
\hline \multirow[t]{3}{*}{$\begin{array}{l}\text { Site } \\
\text { Supervisor }\end{array}$} & $\begin{array}{l}\text { Correlation } \\
\text { Coefficient }\end{array}$ & $726^{* *}$ & $.668^{* *}$ & $.558^{*}$ & $.659^{* *}$ & $.671^{* *}$ & 1.000 & $.785^{* *}$ \\
\hline & $\begin{array}{l}\text { Sig. (2- } \\
\text { tailed) }\end{array}$ & .001 & .005 & .025 & .006 & .004 & & .000 \\
\hline & $\mathrm{N}$ & 16 & 16 & 16 & 16 & 16 & 16 & 16 \\
\hline \multirow[t]{3}{*}{$\begin{array}{l}\text { Architect } \\
\text { and etc. }\end{array}$} & $\begin{array}{l}\text { Correlation } \\
\text { Coefficient }\end{array}$ & $879^{* *}$ & $.832^{* *}$ & $.711^{* *}$ & $.865^{* *}$ & $.741^{* *}$ & $.785^{* *}$ & 1.000 \\
\hline & $\begin{array}{l}\text { Sig. } \\
\text { tailed) }\end{array}$ & .000 & .000 & .002 & .000 & .001 & .000 & \\
\hline & $\mathrm{N}$ & 16 & 16 & 16 & 16 & 16 & 16 & 16 \\
\hline
\end{tabular}

\section{Conclusion and way forward}

The authors tried to disseminate critical information through in-depth analysis towards collected data pertaining the importance of technical competency of construction manager. 
In this instalment, a focus has been made towards screening processes of quantitative data from questionnaire surveys conducted nationwide. Subsequently, central tendency analysis based on mean towards various control variables was subjected to data, before correlation analysis finalised these preliminary procedures. The main purpose of the analysis is not just to reduce prior assumption regarding the nature of data, but to shed light on substantive control variable to be focused on successive stages.

During screening processes of data, aside from exploring data dimensionality [18], the authors stressed on outliers test, reliability test, and normality test as basis for preliminary analysis. Prior to that, collected responses were sieved thoroughly, where incomplete, blank, and unsuitable responses (such as giving improper responses' signs) were rejected in order to maintain clean and full-bodied data. Following the results of screening undertakings, data were free from outlier and showed high reliability. Apart, normality test was confirmed with non-normal nature of data which typically associated with Likert scale, where data are considered ordinal. As far as the research is concerned, outlier's data will influence subsequent analysis, where apparent variability of findings might appear in the latter stages. More often than not, outlier's data will be treated in the first place by researcher before proceeding towards main analysis. Besides, high reliability value $(\alpha)$ in the paper (see Table 1) is very close to the authors' prior findings [18] through Rasch reliability of item and person. Therefore, the authors were optimist that the internal consistency of data is acceptable. In addition, since data are observed to be ordinal, careful selection of subsequent tests is paramount in order to maintain relevant findings, where reliance towards non-parametric type of analysis is inevitable.

Analysis of central tendency (i.e. mean) outlays comparable findings, where recorded means of items' important level are in the range of important (4.00) to very important (5.00). Only handful cases of lower than important (4.00) can be found especially towards different clusters of contractors' grades. By referring to Table 6, contractors of grade 5 and 6 recorded sub 4.00 for PLMED and COMED, which turned the items into among the lowest ranks. On the other hand, largely, correlation strength of items (which reduced to macro level of 16 items) was within the acceptable range of moderate to strong, despite diverse clusters across multiple control variables. Nevertheless, similarly with findings from previous analysis, weak correlations were mainly identified within several contractors' grades especially towards grade 2 contractors (see Table 9). Although positive correlations were recorded, lower correlation index (at $r \leq 0.5)$ signifies questionable degree of association among responses which eventually affect their relationship.

In a nutshell, the findings in this paper echoed previous authors' exploration on central phenomenon in hand as can be perused in Yaman et al. and Mohammad et al. [7, 6]. Due to rigorous processes of initial qualitative endeavours, variability of results throughout these quantitative undertakings was kept at minimum. Nonetheless, further analysis is indeed needed in order to seek significance of items (e.g. their critical $p$-values) especially towards different contractors' grades since the existence of discrepancies eventually posted several latent inquiry, which usually relates to 'why' the circumstances persisted. Moreover, generalisation of findings (e.g. through Kruskall-Wallis H test) across various contractors' grades is also paramount before establishment of technical competency of construction manager can be made.

\section{References}

[1] Construction Industry Development Board, Construction industry transformation programme (CITP) 2016-2020: Driving construction excellence together, Kuala Lumpur, (2015) 
[2] H. Abdul-Rahman, M.A. Berawi, A.R. Berawi, O. Mohamed, M. Othman and I.A. Yahya, Delay mitigation in the Malaysian construction industry, J. of Construction Engineering and Management, 132(2), 125-133 (2006)

[3] A.R. Ibrahim, M.H. Roy, Z. Ahmed and G. Imtiaz, An investigation of the status of the Malaysian construction industry, Benchmarking, 294-308 (2010)

[4] National Audit Department Malaysia, Auditor general's report: Government's financial statement, financial management for the year 2013 and activities of the federal ministries/departments and management of the government companies (series three), Kuala Lumpur, (2013)

[5] Unit Penyelarasan Pelaksanaan, Jabatan Perdana Menteri, Pengurusan projek sektor awam. bengkel penggubalan modul dan kaedah pelaksanaan kursus pensijilan pengurusan projek sektor awam, Kuala Lumpur, (2013)

[6] H. Mohammad, S. Yaman, F. Hassan and Z. Ismail. determining the technical competencies of construction managers in the Malaysia's construction industry, MATEC Web of Conferences, 47, 04021 (2016)

[7] S. Yaman, A. Abdullah, H. Mohammad and F. Hassan, technical competency of construction manager in Malaysian construction industry, Applied Mechanics and Materials, 773-774, 1053-1059 (2015)

[8] S. Walfish, A review of statistical outlier methods, Pharmaceutical Technology, 30(11), 1-5 (2006)

[9] R. Dawson, How significant is a boxplot outlier?, J. of Statistics Education, 19(2), 1-13 (2011)

[10]J. A. Gliem and R.R. Gliem, Calculating, interpreting, and reporting Cronbach's alpha reliability coefficient for likert-type scales, Midwest Research to Practice Conf. in Adult, Continuing, and Community Education, Ohio, (2003)

[11]M. Tavakol and R. Dennick, Making sense of Cronbach's alpha, Int. J. of Medical Education, 2, 53-55 (2011)

[12]A. Ghasemi and S. Zahediasl, Normality tests for statistical analysis: A guide for nonstatisticians, Int. J. of Endocrinology and Metabolism, 10(2), 486-489 (2012)

[13]J.W. Creswell, Educational research: Planning, conducting, and evaluating quantitative and qualitative research (3rd ed.), Pearson, Ohio, (2008)

[14]D.P. Doane and L.E. Seward, Measuring skewness: A forgotten statistic?, J. of Statistics Education, 19(2), 1-18 (2011)

[15]H.Y. Kim, Statistical notes for clinical researchers: Assessing normal distribution (2) using skewness and kurtosis, Restorative Dentistry and Endodontics, 38(1), 52-54 (2013)

[16]P. Singh, P.A. Ghani and T.S Hoon, Quantitative data analysis for novice researchers, Primera Publishing, Kuala Lumpur, (2009)

[17]N. Ghazali, S. Yaman and H. Mohammad, Contractors' compliance on occupational safety and health (OSH) policies in Malaysia's construction industry, Proc. 8th MUCET, Melaka, (2014)

[18]H. Mohammad, F. Hassan, R. Abd Rashid and S.K. Yaman, Dimensionality analysis of technical competency for Malaysian construction managers, Int. UNIMAS STEM Engineering Conf., Kuching, (2016) 